\title{
Multisatellite-Based Feeding Habitat Suitability Modeling of Albacore Tuna in the Southern Atlantic Ocean
}

\author{
Ali Haghi Vayghan ${ }^{1}\left(\mathbb{D}\right.$, Ming-An Lee ${ }^{2,3, *}{ }^{\mathbb{D}}$, Jinn-Shing Weng ${ }^{4}$, Sandipan Mondal ${ }^{2,3}$, \\ Ching-Te Lin ${ }^{2}$ and Yi-Chen Wang ${ }^{2,3}$ \\ 1 Department of Ecology \& Aquatic Stocks Management, Artemia \& Aquaculture Research Institute, \\ Urmia University, P.O. Box 57179-44514, Urmia 57179-44514, Iran; a.haghi@urmia.ac.ir \\ 2 Department of Environmental Biology Fisheries Science, National Taiwan Ocean University, 2 Pei-Ning Rd., \\ Keelung 20224, Taiwan; mondalsandipan31@gmail.com (S.M.); tomlin1357@gmail.com (C.-T.L.); \\ live723@mail.ntou.edu.tw (Y.-C.W.) \\ 3 Center of Excellence for Ocean Engineering, National Taiwan Ocean University, Keelung 20224, Taiwan \\ 4 Coastal and Offshore Resources Research Center of Fisheries Research Institute, Kaoshiung 80672, Taiwan; \\ j-s.ueng@mail.tfrin.gov.tw \\ * Correspondence: malee@mail.ntou.edu.tw
}

Received: 28 May 2020; Accepted: 1 August 2020; Published: 5 August 2020

\begin{abstract}
Decision strategies in fisheries management are often directed by the geographic distribution and habitat preferences of target species. This study used remote sensing data to identify the optimal feeding habitat of albacore tuna in the Southern Atlantic Ocean (SAO) using an empirical habitat suitability model applying longline fisheries data during 2009-2015. An arithmetic mean model with sea surface temperature (SST) and sea surface chlorophyll-a concentration (SSC) was determined to be suitable for defining the albacore habitat in the SAO. The optimal ranges of SST and SSC for the habitat were approximately $16.5{ }^{\circ} \mathrm{C}-19.5{ }^{\circ} \mathrm{C}$ and $0.11-0.33 \mathrm{mg} / \mathrm{m}^{3}$, respectively. The study revealed a considerable positive trend between the suitable habitat area and standardized catch per unit effort $(r=0.97 ; p<0.05)$; due to the west-to-east and northward development of the suitable habitat, albacore schools moved to the northeast of the SAO, thus increasing catch probability in April to August in that region. Overall, the frontal structure of SST and SSC plays an essential role in the formation of potential albacore habitats in the SAO. Our findings could contribute to the establishment of regional ecosystem-based fisheries management in the SAO.
\end{abstract}

Keywords: albacore tuna; habitat suitability index; longline fishery; fisheries management; multisatellite remote sensing data

\section{Introduction}

Since 1978, multisatellite remote sensing data have been used for obtaining images of ocean sea surface temperature (SST), thermal and chlorophyll-a fronts [1-3], and phytoplankton pigment concentration, all of which have been useful in fisheries management, fisheries oceanography, and operational fisheries oceanography [4-6]. Remote sensing, with its fast and large-scale collection of data, offers enormous potential for the support of fishery exploitation and management of pelagic species [7-10]. It can increase our understanding of tuna habitats and the influencing factors [4,11-13]. Furthermore, data supplied in near-real time help fishermen save fuel and ship time when patrolling for fish, modelers who produce fisheries forecasts, and scientists developing strategies for sustainable fisheries management [14]. In the past decade, remote sensing tools have provided new insights for the promotion of ecosystem-based fisheries management (EBFM), for example, in tuna regional 
fisheries management organizations (RFMOs) [15]. These tools are employed frequently for tuna distribution [13,16-19] and catch per unit effort (CPUE) standardization [20,21]. Hence, remote sensing of the environmental variables that potentially shape habitat preferences can be used to assess the catchability of target species, and thus can be useful for both regional and global EBFM.

Habitat modeling is crucial for EBFM in tuna regions [15]. Indices of abundance using habitat data are used to determine spatiotemporal stock assessment to inform the dynamic of the population [22,23] and has been applied for many fish species throughout the world [24-26]. This methodology has been broadly developed in species monitoring, environmental impact assessment, and ecological recovery studies [27]. Models for potential habitat zones of marine organisms, such as the habitat suitability index (HSI) model, generalized linear model (GLM), and generalized additive model (GAM), have been extensively studied recently. Multisatellite remotely sensed data were used for habitat modeling of albacore tuna (Thunnus alalunga) in the North Pacific Ocean [28]. Wang et al. [29,30] and Alabia et al. [31] have developed a practical model to define the suitable habitat and optimal ranges of environmental factors for a fishing grounds map and spatial shifts of neon flying squid (Ommastrephes bartramii) in the Northwest Pacific Ocean. In addition, Lan et al. [4] used GAMs to study the relationship between remotely sensed variables and catch distribution in the Atlantic Ocean. Zainuddin et al. [9] applied a mixed GAM/GLM with multisatellite environmental data and integrated catch data to produce a simple prediction map for possible fishing grounds during 1998-2000. Thus, habitat suitability modeling, with its pros and cons (just as other methods [26]), is widely used to help decision makers monitor vital commercial fish habitat shifts, fleet behavior, prey abundance, and even climate effects [32] and implement or modify EBFM.

Albacore tuna is among the commercially prominent species in longline fishery; extensive research has been conducted on this species in the South Atlantic Ocean (SAO, Figure 1) [33-35]. Its migratory behavior facilitates its wide distribution in the temperate and tropical waters of the SAO [36]. In general, it is a relatively late-maturing species due to slow growth, with estimates of fork length at $50 \%$ maturity being approximately $90 \mathrm{~cm}$ in the SAO [36,37]. It reaches sexual maturity at about five years, and it is frequently exploited using longline, troll, and pole-and-line gear in the SAO [36]. Potential feeding areas for albacore seem to occur during the austral winter in the SAO (Figure 1), whereas potential spawning areas appear to be spatially restricted to the western basins in the South Atlantic and Indian Oceans [36]. Albacore, based on their physiological and ecological features, are likely to prefer a specific range of environmental factors that can be remotely sensed. For example, Zainuddin et al. [38] determined that intense fishing activity and larger catches of albacore were located in the productive area close to a thermal front. Chen et al. [39] reported that the distribution of high CPUEs of albacore in the Indian Ocean is associated with warm SST isotherms and high chlorophyll-a concentration, particularly for immature fish. SST and chlorophyll-a concentrations affect distribution patterns and variability in tuna abundance [9,38]. Thus, albacore distribution and abundance are sensitive to environmental factors and are strongly associated with high forage density (e.g., [9,38,40]). The annual catch of South Atlantic albacore was 25,000-35,000 mt over the last decade, and it comprises $\geq 70 \%$ of the total catch of Taiwanese longliners in the SAO [41]. According to an International Commission for the Conservation of Atlantic Tunas (ICCAT) report, albacore tuna stock has been in an overfished state since 1990 [37]. In the context of sustainable fisheries management, the main objective of EBFM translates into guaranteeing the sustainability of harvests without compromising the shape and functioning of marine ecosystems [15]. Many studies have focused on fishery biology, population structure, distribution, and migration [33,37,42-44], but few have investigated essential fish habitat, especially in the SAO [36,45]. Thus, developing a habitat model using multisatellite remotely sensed data is critical, as it might provide new insights into promoting EBFM in regional tuna fisheries management organizations [15]. On the other side, less attention has been paid to SAO in comparing with other ecosystems worldwide, especially using recent Taiwanese longline data in defining albacore feeding habitat. However, the present study developed a practical habitat suitability model for detecting the most preferred feeding habitats of albacore tuna and described environmental variables ranges that 
shaped the habitats by applying multisatellite remotely sensed data combined with longline fishing data for the SAO.
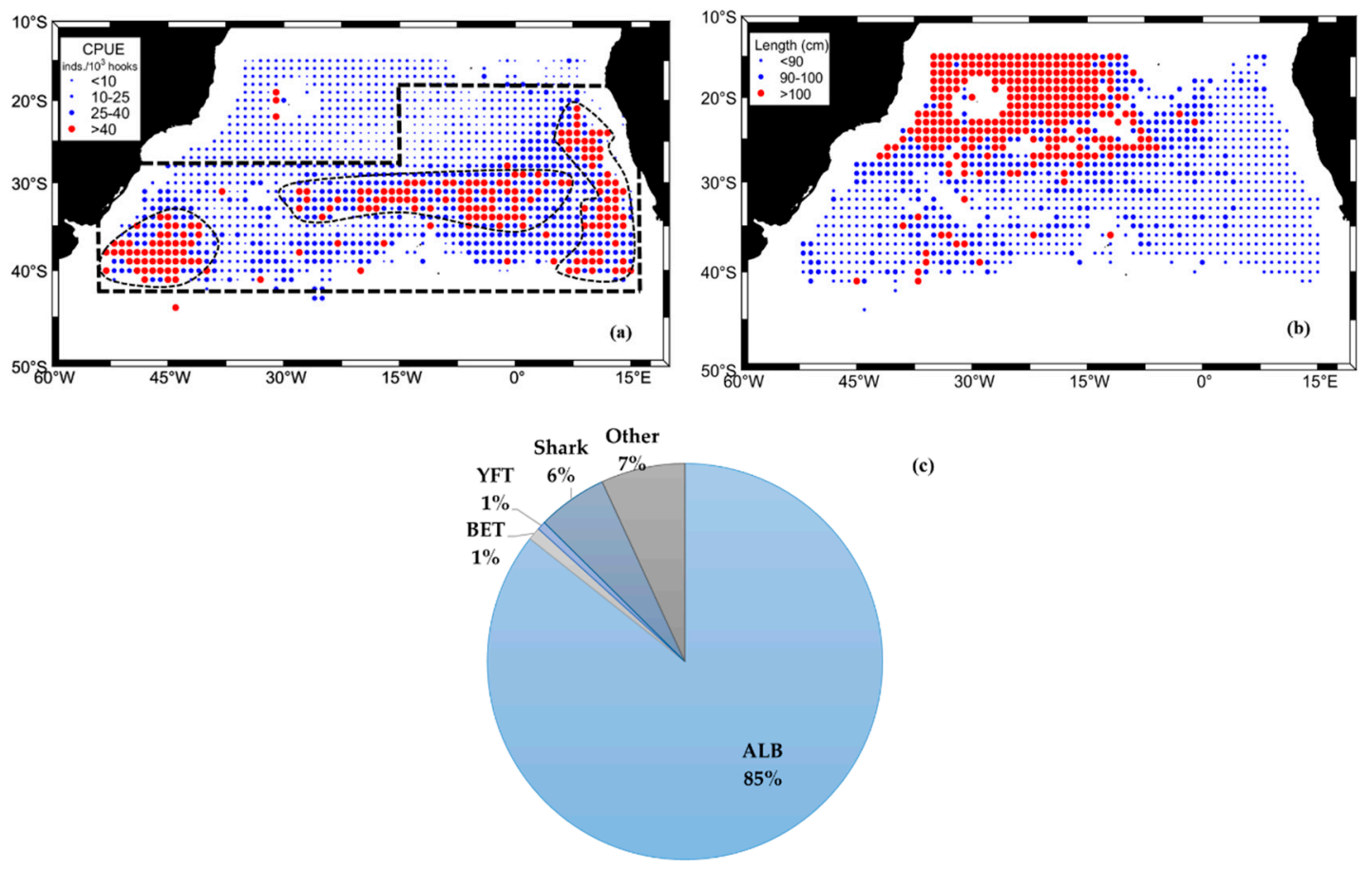

(c)

$\square$ ALB $\square$ BET $\square$ YFT $\square$ Shark $\square$ Other

Figure 1. Study area: (a) geographical distribution of albacore tuna in nominal catch per unit effort (CPUE) (dashed line represents feeding ground and dashed circle denotes CPUE > 40); (b) average length distribution; and (c) catch composition (\% of total catch) for Taiwanese large-scale longliners during 2009-2015 in the Southern Atlantic Ocean (SAO).

\section{Materials and Methods}

\subsection{Albacore Tuna Fishing Fleet Data}

Albacore fishery data were collected from the logbooks of Taiwanese longline fishing fleets in the SAO, which were supplied by the Overseas Fisheries Development Council of Taiwan. In total, 6192 pooled $1^{\circ} \times 1^{\circ}$ spatial records from the Taiwanese longline fleets throughout the annual fishing seasons of 2009-2015 were applied in the analyses. Data were collected for calculation and inputted into the models. The fishery data comprised number of catches, fishing effort (number of hooks), position (latitude and longitude), and date. All data were assessed and verified by the observer program of Taiwan's Fisheries Agency, though uncertainty of the catch data has been discussed in global marine fisheries [46]. The effort and catch data were further pooled by year and month using a $1^{\circ} \times 1^{\circ}$ spatial grid.

No significant bycatch (more than $85 \%$ of the catch was detected as the target fish; Figure 1c) was assumed [37], and CPUE (individuals/1000 hooks) of the tuna longline fishery fleets was considered a reliable indicator of stock relative abundance in the fishing regions $[9,10,23]$. Monthly nominal CPUE was computed as the number of fish captured per 1000 hooks (individuals/10 3 hooks).

$$
C P U E_{i j k}=\sum C_{i j k} / \sum E_{i j k}
$$

where CPUE $E_{i j k}$ is the nominal CPUE (individuals/1000 hooks), $\sum C_{i j k}$ and $\sum E_{i j k}$ are the total catch and fishing effort (1000 hooks) in the $1^{\circ} \times 1^{\circ}$ grid, respectively, and $i, j$, and $k$ represent the month, longitude, and latitude, respectively. 


\subsection{Nominal CPUE Standardization}

Nominal CPUE may be affected by the function of some set of covariates (e.g., year, month, longitude, latitude), leading to unintentional overestimation of a relative abundance index $[10,20,47,48]$. A GLM was therefore applied to standardize CPUE as follows:

$$
\log (\text { cpue }+c)=\mu+\text { year }+ \text { month }+ \text { longitude }+ \text { latitude }+\varepsilon
$$

where cpue is the nominal CPUE, $\mathrm{c}$ is a constant value of $0.1 \%$ or $10 \%$ of the overall mean of the nominal catch rates, which is commonly used in standardizations (e.g., $[10,20]), \mu$ is the intercept, and $\varepsilon$ is a normally distributed variable with a mean equal to zero. Thus, in the forthcoming analysis, we used the standardized CPUE to remove the influence of covariates.

\subsection{Satellite Remote Sensing Data}

Remotely sensed environmental variables and satellite altimetry products from 2009 to 2015, including SST, sea surface chlorophyll-a concentration (SSC), sea surface salinity (SSS), sea surface height (SSH), mixed layer depth (MLD), and eddy kinetic energy (EKE), were hypothesized to be associated with albacore catch potential $[5,8,27,37,39]$ and were analyzed in this study. The monthly satellite data during 2009-2015 in Table 1 were obtained from online databases as follows: (i) data on SST and SSC monthly composite fields were collected from the ERDDAP data server of the National Oceanic and Atmospheric Administration (https://coastwatch.pfeg.noaa.gov/erddap/index.html), (ii) SSH and EKE were obtained from AVISO, (iii) SSS was obtained from MOVE-MRI, and (iv) MLD was obtained from HYCOM (Naval Research Laboratory at Stennis Space Center; http://www.hycom.org/). U and V current data were also obtained from AVISO to calculate EKE $\left(E K E=0.5\left(\mathrm{U}^{2}+\mathrm{V}^{2}\right)\right)$. All the remote sensing variables were then resampled and computed as monthly means on a lower spatial grid of $1^{\circ}$ $\times 1^{\circ}$ resolution to meet the spatial resolution of fishery data.

Table 1. Multisatellite remote sensing variables and satellite altimetry data sources and definitions of environmental factors applied in the model.

\begin{tabular}{cccc}
\hline Habitat Variables & Units & Data Source & Resolution \\
\hline Sea Surface Temperature (SST) & ${ }^{\circ} \mathrm{C}$ & MODIS & $4 \mathrm{~km} \times 4 \mathrm{~km}$ \\
Sea surface chlorophyll-a (SSC) & $\mathrm{mg} \mathrm{m}^{-3}$ & MODIS & $4 \mathrm{~km} \times 4 \mathrm{~km}$ \\
Sea Surface Salinity (SSS) & $\mathrm{psu}$ & MOVE-MRI & $10 \mathrm{~km} \times 10 \mathrm{~km}$ \\
Sea Surface Height (SSH) & $\mathrm{cm}$ & AVISO & $25 \mathrm{~km} \times 25 \mathrm{~km}$ \\
Mixed Layer Depth (MLD) & $\mathrm{m}$ & HYCOM & $1 / 12^{\circ} \times 1 / 12^{\circ}$ \\
Eddy Kinetic Energy (EKE) & $\mathrm{m}^{2} \mathrm{~s}^{-2}$ & AVISO & $25 \mathrm{~km} \times 25 \mathrm{~km}$ \\
\hline
\end{tabular}

\subsection{Suitability Index of CPUE and Environmental Variables}

To clarify the relationship between environmental preferences and the stock abundance index (i.e., standardized CPUE) of the fishing grounds, a suitability index (SI) for albacore was calculated based on the central tendency of habitat factors [28] by fitting the standardized CPUE data and environmental variables in the specific month, longitude, and latitude by using smoothing spline regression [24-26,28,49]. In constructing the SI model, the stock abundance index was assumed as the dependent (or response) variable, and environmental variables were used as the independent (or explanatory) variable. Hence, standardized CPUE and environmental variables (SST, SSC, SSS, MLD, SSH, and EKE) were applied and then normalized (scaled from 0 to 1 ) as follows [24,26,49]:

$$
S I=\frac{\hat{Y}_{i j k}-\hat{Y}_{i j k} \min }{\hat{Y}_{i j k} \max -\hat{Y}_{i j k} \min }
$$


where $\hat{Y}$ is the predicted CPUE or environmental variable, $\hat{Y}_{\max }$ and $\hat{Y}_{\min }$ are the maximum and minimum observations of CPUE or environmental data, respectively, and $i, j$, and $k$ represent the month, longitude, and latitude, respectively.

The summed frequency distribution of standardized CPUE of each class was used to calculate the SI values. Then, each SI was assumed ranging between 0 and 1 . The calculated SI values for each environmental variables based on Equation (3) were used as observed values to fit SI models with the midpoints of each environmental variables class interval. Finally, the relationship between SI and selected environmental variables were calculated using the following formula described by Chen et al. [50] and Lee et al. [51,52]:

$$
S I_{m}=e^{\left(\alpha(m+\beta)^{2}\right)}
$$

where $m$ denotes the response variable (such as SSC or SST), and $\alpha$ and $\beta$ are fixed by applying the least squares estimate to minimize the residual between SI observation and SI function.

\subsection{Development of the HSI Model}

The SI values prepared from each environmental factor of the fishing grounds were inputted into a common empirical HSI model $[7,25,26]$. Two of the most common empirical HSI models-the arithmetic mean model (AMM) [28,53] and the geometric mean model (GMM) [28,54]—are generally employed to evaluate habitat accessibility $[7,28]$. HSI is assumed to be a univariate variable range between 0 and 1 [55]. The AMM and GMM empirical HSI models were calculated as follows:

$$
\begin{gathered}
H S I_{A M M}=\frac{1}{m} \sum_{n=1}^{m} S I_{n} \\
H S I_{G M M}=\left(\prod_{n=1}^{m} S I_{n}\right)^{1 / m}
\end{gathered}
$$

where $S I_{n}$ represents the SI for the $n$th environmental factor, $m$ is the number of environmental factors applied in the model, and $n$ is $1,2, \ldots$, and $m$.

We assumed SST to be the principal factor for defining the habitat for albacore according to studies on the association between environmental variables and albacore catch [28]. We then applied different forward combinations of two to six variables as habitat data in each empirical habitat model. SI values $>0.6$, obtained from various integrations of habitat factors, were then incorporated into the HSI model [28].

\subsection{Model Selection and Validation}

Model performance of the computed albacore HSIs (again, with one to six environmental variables) was evaluated and compared to identify the most appropriate HSI model based on Akaike's information criterion (AIC; [53]). The model that yielded the lowest AIC value was selected as the best model and then used for model testing and validation. Model performance was evaluated based on summed monthly standardized CPUE from 2009 to 2015 tested according to intervals of analyzed HSI values (see Lee et al. [51,52]). Then, the goodness of fit of the linear correlation between CPUE and HSI values was also evaluated based on the minimum AIC value, with adjusted $R^{2}$ to justify the HSI model for the prediction of potential habitats. Finally, the spatial distributions of HSI values determined using the selected HSI model were mapped using IDL Version 7.0 (Environmental Simulation Laboratory Co., Ltd., Saitama, Japan) to predict potential feeding habitats (or fishing grounds), and these were compared with actual fishery data from longliners. 


\section{Results}

\subsection{Spatiotemporal Variations in Fishing Effort, Catch, and CPUE in the SAO}

Spatial distributions of monthly means of fishing effort, catch, and CPUE per one-degree square from 2009 to 2015 are presented in Figure 2. The monthly fishing effort and catch differed spatially by feeding ground, whereas CPUEs larger than 40 individuals/1000 hooks were focused in the three regions of $52^{\circ} \mathrm{W}-40^{\circ} \mathrm{W}, 35^{\circ} \mathrm{S}-42^{\circ} \mathrm{S}, 19^{\circ} \mathrm{W}-2^{\circ} \mathrm{E}, 30^{\circ} \mathrm{S}-34^{\circ} \mathrm{S}$, and $20^{\circ} \mathrm{W}-17^{\circ} \mathrm{E}, 25^{\circ} \mathrm{S}-40^{\circ} \mathrm{S}$ (Figure 1 ). The lowest and highest monthly catches (i.e., fishing effort) were approximately 5100 individuals (45,000 hooks) and 143,400 individuals (3,750,000 hooks) in 2014 and 2011, respectively (Figure 2a). In addition, the major fishing season was the end of summer to winter in the southern hemisphere (April to August), and the mean monthly standardized CPUE was $24.54 \pm 4.08$ individuals/1000 hooks (Figure 2d). Mean monthly standardized CPUE was the highest in June at $36.39 \pm 4.55$ individuals/1000 hooks (Figure $2 \mathrm{~d}$ ), whereas the range of standardized CPUE was 7.44 to 41.53 individuals/1000 hooks (Figure 2c). Statistical analysis for CPUE and standardized CPUE is shown in Tables S1 and S2 (see supplementary materials) in the supplementary material. Pearson coefficient value of CPUE and standardized CPUE for monthly mean and the entire time series were 0.864 and 0.495 , respectively, whereas $F$ test of CPUE and standardized CPUE for monthly mean and the entire time series showed a value of 254.181 and 2011.451, respectively. Pearson correlation analysis showed a strong relation between CPUE and standardized CPUE for the monthly mean than the entire time series.
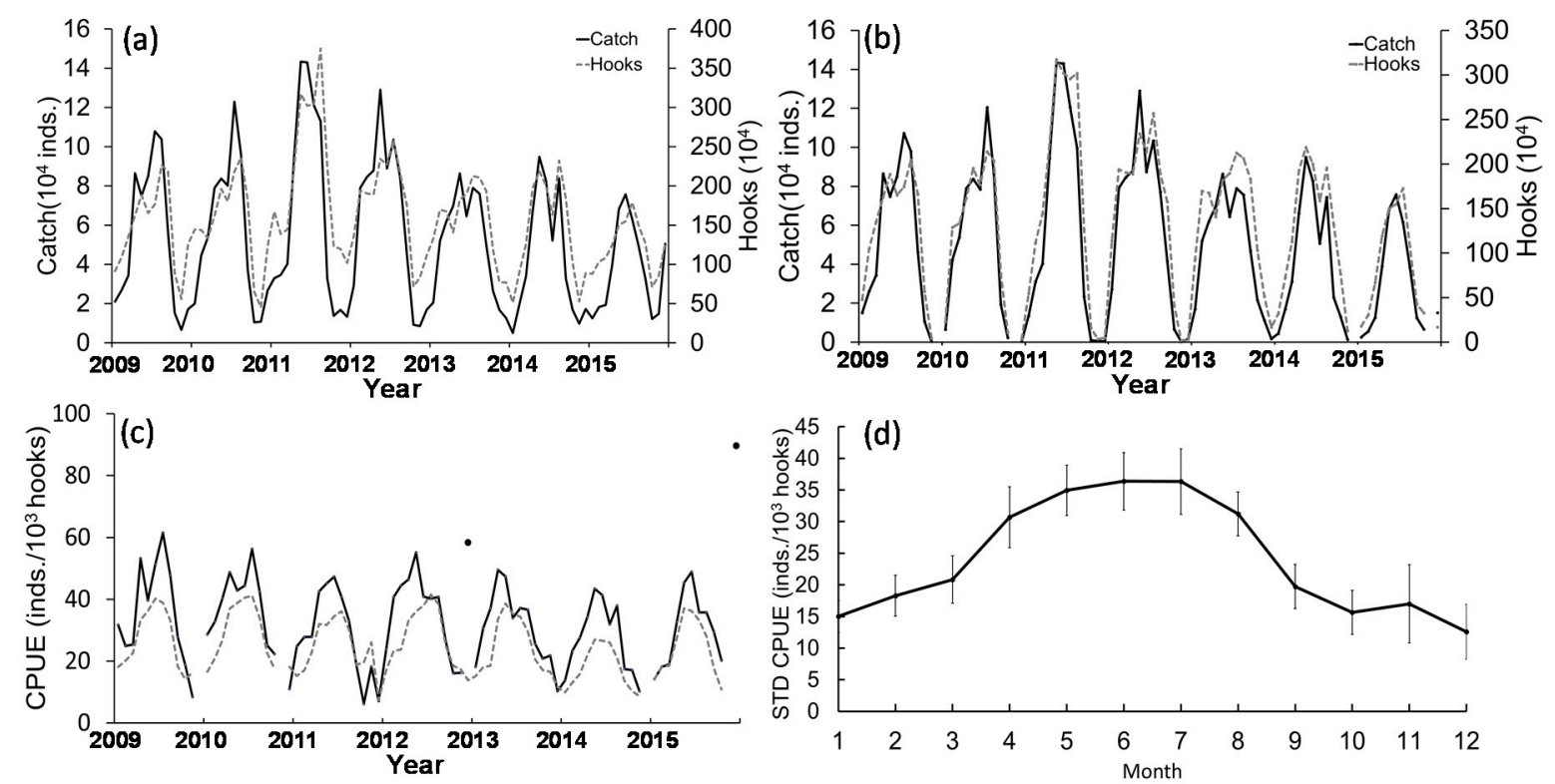

Figure 2. Monthly changes of fishing effort (number of hooks) and catch in (a) entire fishing area, (b) feeding area, (c) time series of monthly mean CPUE and standardized CPUE trends, and (d) the frequency distribution of standardized CPUE (bar plot denotes \pm standard deviation) from 2009 to 2015 in the SAO.

\subsection{Remotly Sensed Environmental Variables in the SAO}

To identify high albacore abundance, we focused on satellite remote sensing variables collected over Taiwanese longliners in the SAO. The monthly means and standard deviations of SST, SSS, SSC, SSH, MLD, and EKE for 2009-2015 were mapped (Figure 3). The monthly SST corresponded to the latitude and increased from the south to the north. SST lower than $20^{\circ} \mathrm{C}$ was located south of $32^{\circ} \mathrm{S}$, where the standard deviation was comparatively low at almost $1.5^{\circ} \mathrm{C}$ per one-degree square (Figure 3 ). A $15^{\circ} \mathrm{C}-16^{\circ} \mathrm{C}$ swath of SST appeared in $37^{\circ} \mathrm{S}-40^{\circ} \mathrm{S}$ (Figure 3). High deviations in SST were detected in the limited areas of $48^{\circ} \mathrm{W}-54^{\circ} \mathrm{W}$ and $30^{\circ} \mathrm{S}-40^{\circ} \mathrm{S}$ (Figure 3). The spatial pattern of mean and standard 
deviation of SSS was almost identical to that of SST, with high SSS deviations occurring in $27^{\circ} \mathrm{S}-40^{\circ} \mathrm{S}$ and $42^{\circ} \mathrm{W}-52^{\circ} \mathrm{W}$ (Figure 3 ).

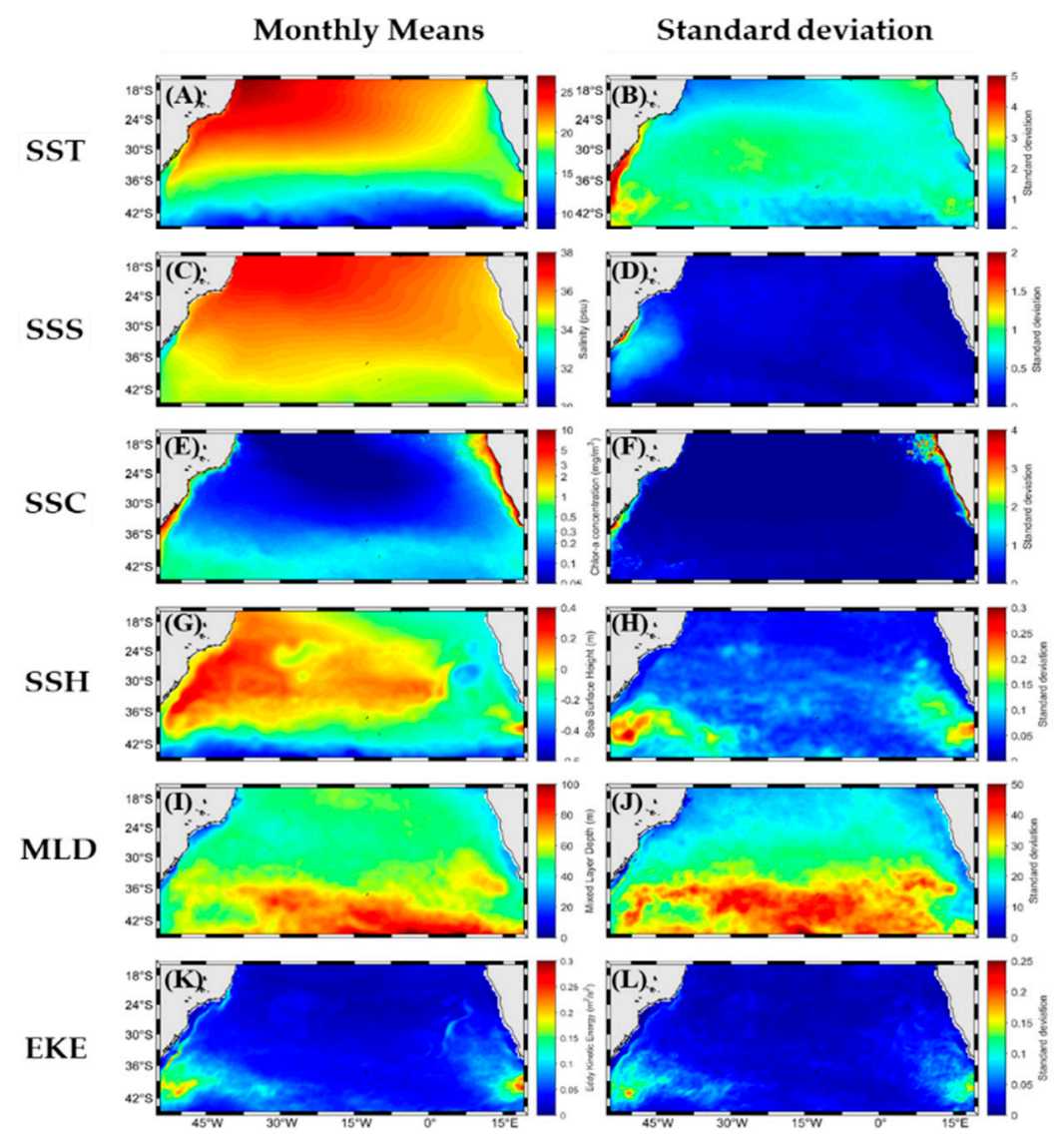

Figure 3. Monthly means and standard deviations of SST, SSS, SSC, SSH, MLD, and EKE ((A-L), respectively) from 2009 to 2015.

SSC $>0.25 \mathrm{mg} / \mathrm{m}^{3}$ was found south of $35^{\circ} \mathrm{S}$, and deviations were generally low (Figure 3). The highest SSH values were observed in the low-latitude waters north of $42^{\circ} \mathrm{S}$ (Figure 3), whereas the highest MLD values were located south of $35^{\circ} \mathrm{S}$ (Figure 3), with considerable variations in deviation (Figure 3).

\subsection{SI Curves and HSI Modeling of Albacore}

Considering SI $>0.6$, the optimal ranges [49] (Figure 4) of albacore habitat for the environmental variables of SST, SSS, SSC, SSH, MLD, and EKE were $16.5^{\circ} \mathrm{C}-19.5^{\circ} \mathrm{C}, 35.1-35.9 \mathrm{psu}, 0.11-0.33 \mathrm{mg} / \mathrm{m}^{3}$, $-0.22-0.18 \mathrm{~m}, 45-95 \mathrm{~m}$, and $0.09-0.039 \mathrm{~m}^{2} \mathrm{~s}^{-2}$, respectively. The AMM HSI model with two variables (i.e., SST and SSC) detected using lower AIC values (-77.63) had the best fit (Table 2). The AMM HSI model with three variables (SST, SSH, and EKE) provided the same AIC values (-77.63); however, it gained lower adjusted $R^{2}(r=0.63)$ than the model with SST and SSC $(r=0.90)$. 
Table 2. Comparison of two empirical HSI models using forward stepwise with six satellite remotely sensed environmental factors for albacore in the SAO. Average CPUE displayed a high adjusted $R^{2}(r=0.90)$ and the lowest AIC (-77.63) (highlighted in bold format) with the AMM-based HSI values; the AMM-derived HSI model using SST and SSC best predicted SAO albacore habitat suitability.

\begin{tabular}{|c|c|c|c|c|c|c|c|c|c|c|c|c|}
\hline \multirow{2}{*}{$\begin{array}{l}\text { Environmental } \\
\text { Variables }\end{array}$} & \multicolumn{6}{|c|}{ AMM } & \multicolumn{6}{|c|}{ GMM } \\
\hline & $\alpha$ & $\beta$ & $P(F)$ & Adjusted $R^{2}$ & AIC & $\triangle \mathrm{AICw}$ & $\alpha$ & $\beta$ & $\mathbf{P}(\mathbf{F})$ & Adjusted $R^{2}$ & AIC & $\triangle \mathrm{AICw}$ \\
\hline sst & 0.959 & 0.051 & $<0.001$ & 0.74 & -61.75 & 15.88 & 0.959 & 0.051 & $<0.001$ & 0.74 & -61.75 & 8.74 \\
\hline sst, ssc & 0.097 & 0.041 & $<0.001$ & 0.90 & -77.63 & 0.00 & 0.095 & 0.052 & $<0.001$ & 0.84 & -67.77 & 2.72 \\
\hline sst, mld & 0.100 & 0.039 & $<0.001$ & $\overline{0.61}$ & -61.3 & $\overline{16.33}$ & 0.081 & 0.075 & $<0.001$ & 0.86 & -61.67 & 8.82 \\
\hline sst, ssh & 0.067 & 0.089 & $<0.001$ & 0.91 & -62.63 & 15 & 0.098 & 0.045 & $<0.001$ & 0.70 & -62.65 & 7.84 \\
\hline sst, sss & 0.088 & 0.057 & $<0.001$ & 0.91 & -71.62 & 6.01 & 0.099 & 0.040 & $<0.001$ & 0.67 & -63.20 & 7.29 \\
\hline sst, eke & 0.116 & 0.015 & $<0.001$ & 0.15 & -62.74 & 14.89 & 0.113 & 0.016 & $<0.001$ & 0.23 & -64.66 & 5.83 \\
\hline sst, ssc, mld & 0.067 & 0.089 & $<0.001$ & 0.89 & -61.4 & 16.23 & 0.083 & 0.071 & $<0.001$ & 0.93 & -70.49 & 0.00 \\
\hline sst, ssc, ssh & 0.099 & 0.038 & $<0.001$ & 0.65 & -63.56 & 14.07 & 0.094 & 0.053 & $<0.001$ & 0.85 & -67.80 & $\overline{2.69}$ \\
\hline sst, ssc, sss & 0.095 & 0.047 & $<0.001$ & 0.73 & -63.06 & 14.57 & 0.101 & 0.041 & $<0.001$ & 0.70 & -64.46 & 6.03 \\
\hline sst, ssc, eke & 0.116 & 0.017 & $<0.001$ & 0.15 & -60.39 & 17.24 & 0.109 & 0.025 & $<0.001$ & 0.32 & -59.76 & 10.73 \\
\hline sst, mld, ssh & 0.073 & 0.076 & $<0.001$ & 0.91 & -65.91 & 11.72 & 0.083 & 0.069 & $<0.001$ & 0.88 & -65.60 & 4.89 \\
\hline sst, mld, sss & 0.062 & 0.095 & $<0.001$ & 0.84 & -55.26 & 22.37 & 0.099 & 0.044 & $<0.001$ & 0.61 & -59.27 & 11.22 \\
\hline sst, mld, eke & 0.081 & 0.068 & $<0.001$ & 0.83 & -61.75 & 15.88 & 0.111 & 0.023 & $<0.001$ & 0.35 & -62.93 & 7.56 \\
\hline sst, ssh, sss & 0.098 & 0.041 & $<0.001$ & 0.88 & -75.57 & 2.06 & 0.108 & 0.028 & $<0.001$ & 0.53 & -64.96 & 5.53 \\
\hline sst, ssh, eke & 0.113 & 0.018 & $<0.001$ & 0.63 & -77.63 & $\underline{0.00}$ & 0.118 & 0.009 & $<0.001$ & 0.04 & -66.49 & 4.00 \\
\hline sst, sss, eke & 0.116 & 0.017 & $<0.001$ & $\overline{0.30}$ & -66.21 & $\overline{11.42}$ & 0.110 & 0.019 & $<0.001$ & 0.10 & -54.95 & 15.54 \\
\hline sst, ssc, mld, ssh & 0.050 & 0.103 & $<0.001$ & 0.94 & -65 & 12.63 & 0.082 & 0.073 & $<0.001$ & 0.92 & -67.89 & 2.60 \\
\hline sst, ssc, mld, sss & 0.097 & 0.061 & $<0.001$ & 0.88 & -58.06 & 19.57 & 0.099 & 0.046 & $<0.001$ & 0.67 & -60.73 & 9.76 \\
\hline sst, ssc, mld, eke & 0.070 & 0.077 & $<0.001$ & 0.61 & -41.49 & 36.14 & 0.108 & 0.031 & $<0.001$ & 0.42 & -58.85 & 11.64 \\
\hline sst, ssc, ssh, sss & 0.108 & 0.026 & $<0.001$ & 0.20 & -46.65 & 30.98 & 0.105 & 0.036 & $<0.001$ & 0.57 & -61.58 & 8.91 \\
\hline sst, ssc, ssh, eke & 0.158 & -0.045 & $<0.001$ & 0.03 & -44.22 & 33.41 & 0.113 & 0.020 & $<0.001$ & 0.21 & -60.16 & 10.33 \\
\hline sst, mld, ssh, sss & 0.057 & 0.090 & $<0.001$ & 0.88 & -50.85 & 26.78 & 0.104 & 0.037 & $<0.001$ & 0.57 & -61.41 & 9.08 \\
\hline sst, mld, ssh, eke & 0.111 & 0.018 & $<0.001$ & 0.43 & -58.73 & 18.9 & 0.113 & 0.018 & $<0.001$ & 0.21 & -61.46 & 9.03 \\
\hline sst, mld, sss, eke & 0.096 & 0.040 & $<0.001$ & 0.62 & -52.1 & 25.53 & 0.109 & 0.024 & $<0.001$ & 0.18 & -55.09 & 15.40 \\
\hline sst, ssc, mld, ssh, sss & 0.072 & 0.074 & $<0.001$ & 0.94 & -59.7 & 17.93 & 0.102 & 0.043 & $<0.001$ & 0.61 & -59.98 & 10.51 \\
\hline sst, ssc, mld, ssh, eke & 0.092 & 0.049 & $<0.001$ & 0.84 & -57.7 & 19.93 & 0.109 & 0.032 & $<0.001$ & 0.37 & -56.83 & 13.66 \\
\hline sst, ssc, mld, sss, eke & 0.113 & 0.021 & $<0.001$ & 0.16 & -48.71 & 28.92 & 0.107 & 0.031 & $<0.001$ & 0.24 & -52.38 & 18.11 \\
\hline sst, ssc, sss, ssh, eke & 0.150 & -0.025 & $<0.001$ & 0.05 & -41.51 & 36.12 & 0.110 & 0.025 & $<0.001$ & 0.13 & -51.38 & 19.11 \\
\hline sst, mld, sss, ssh, eke & 0.087 & 0.053 & $<0.001$ & 0.55 & -45.77 & 31.86 & 0.114 & 0.016 & $<0.001$ & 0.04 & -54.32 & 16.17 \\
\hline sst, ssc, mld, ssh, sss, eke & 0.110 & 0.028 & $<0.001$ & 0.37 & -50.51 & 27.12 & 0.111 & 0.026 & $<0.001$ & 0.15 & -52.25 & 18.24 \\
\hline
\end{tabular}

Abbreviations: AMM, arithmetic mean model; GMM, geometric mean model; $\triangle \mathrm{AICw}$ indicates the variation between the preferred model and the best model within each group 


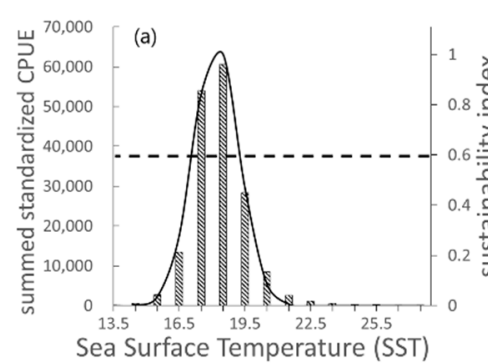

Sea Surface Temperature (SST)

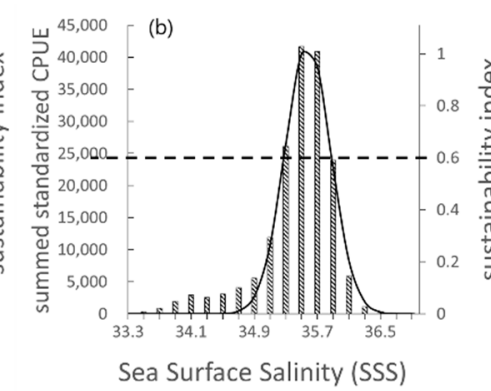

Sea Surface Salinity (SSS)

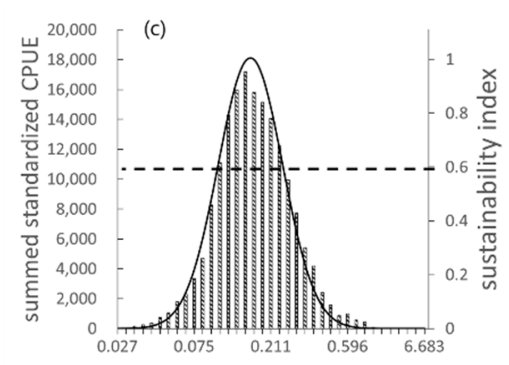

Sea Surface Chlorophyll a (SSC)

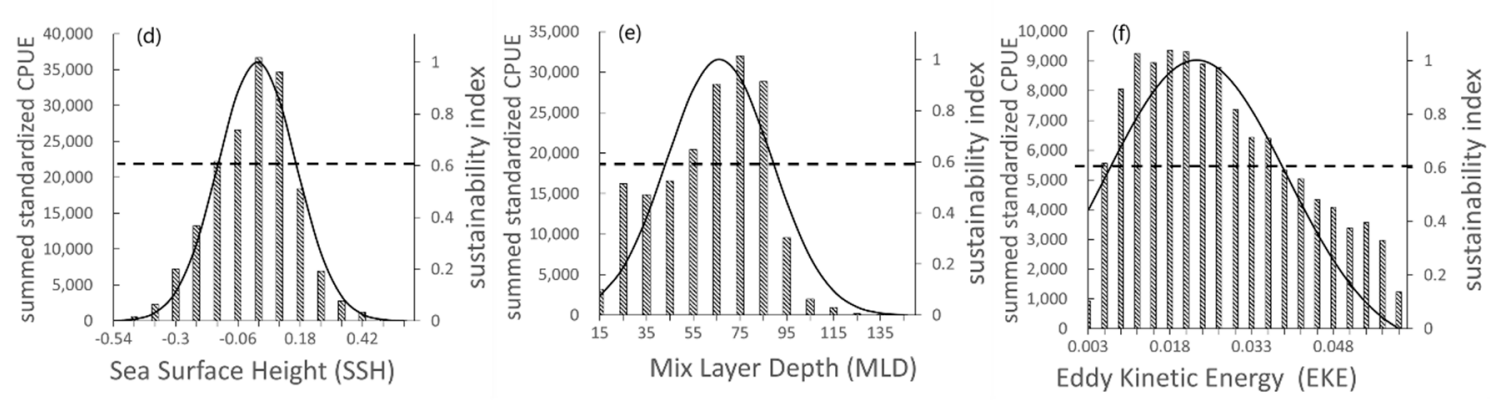

Figure 4. SI curves of (a) SST, (b) SSS, (c) SSC, (d) SSH, (e) MLD, and (f) EKE for albacore using the smoothing spline regression method. The range between the intersections of the SI curve and the horizontal dashed line $(\mathrm{SI}=0.6)$ denotes the optimal range for each environmental variable.

\subsection{HSI Model Validation}

To validate the performance of the AMM, we compared the last year of the average actual values of catch, fishing effort, and summed standardized CPUE of albacore according to the HSI values from both AMMs grouped with the identified environmental factors-SST and SSC or SST, SSH, and EKE-in the study period. The area with HSI $>0.6$ had $47 \%$ and $51 \%$ of the fishing effort and total catch, respectively (Figure 5a). The summed CPUE trend, based on linear regression analysis, was highly correlated $\left(r^{2}=0.975\right)$ with the AMM-based HSI value, and it increased with the HSI value (Figure 5b). The AMM model was therefore a suitable model for predicting albacore HSI.

The temporal AMMs, one with two (SST and SSC) and another with three (SST, SSH, and EKE) variables from all fishing seasons (January to December) between 2009 and 2015, were employed to illustrate the habitats. The monthly spatial distributions of HSI and standardized CPUE were also mapped (Figure 6). A higher cutoff $(>0.6)$ of the predicted monthly mean HSI highlighted a northward shift in the mean position of habitat from approximately $40^{\circ} \mathrm{S}$ in January to approximately $18^{\circ} \mathrm{S}$ in August and September. However, HSI values higher than 0.6 (based on the AMM model with SST and SSC data) were extensively distributed in the areas between $36^{\circ} \mathrm{S}-40^{\circ} \mathrm{S}, 15^{\circ} \mathrm{E}-42^{\circ} \mathrm{W}$ in April and $32^{\circ} \mathrm{S}-20^{\circ} \mathrm{S}, 8^{\circ} \mathrm{E}-44^{\circ} \mathrm{W}$ (a northeast direction) in August. Furthermore, the predicted HSI maps indicated that the spatial distribution of albacore CPUE varied by month, with a more concentrated distribution corresponding to the area with the optimum HSI value (>0.6) (Figure 6a,b), and CPUE followed a similar pattern corresponding to optimal HSI value distribution. In April, the optimum HSI value was distributed in $36^{\circ} \mathrm{S}-40^{\circ} \mathrm{S}$, with a low HSI value $(<0.4)$ in waters north of $32^{\circ} \mathrm{S}$. In May to August, the area of the optimum HSI value with CPUE $>40$ individuals/ 1000 hooks, preferred by Taiwanese fishermen, moved slightly northward (near $\left.18^{\circ} \mathrm{S}-32^{\circ} \mathrm{S}\right)$ as well as eastward $\left(0^{\circ} \mathrm{E}-11^{\circ} \mathrm{E}\right)$, and the area with low HSI moved slightly southward in August, lying to the south of $40^{\circ} \mathrm{S}$, compared with the position (north of $30^{\circ} \mathrm{S}$ ) in April. In addition, the spatial map of standardized CPUE and the calculated empirical HSI AMM model with two variables (SST and SSC) was similar to that of the AMM model with three (SST, SSH, and EKE) variables, with obvious northeast movements in both HSI and standardized CPUE. 

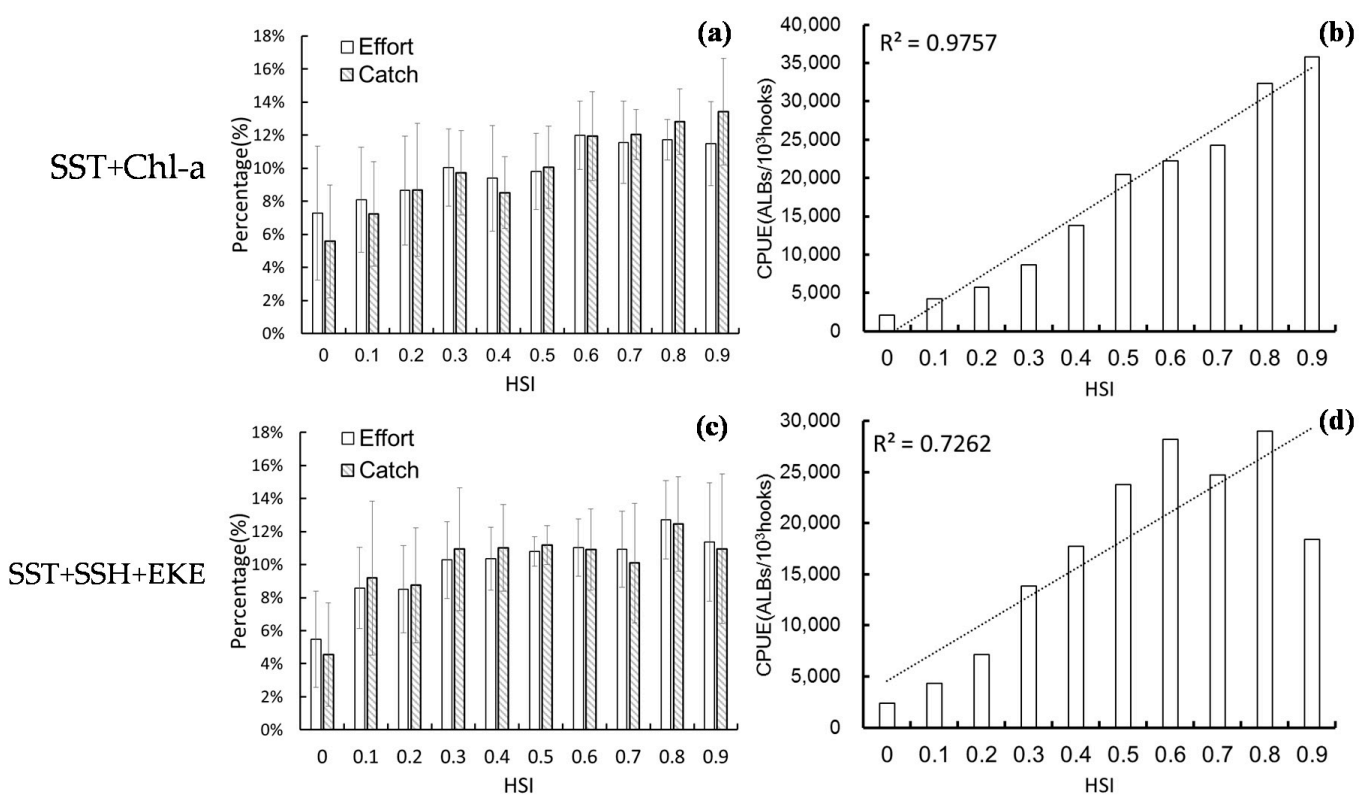

(d)

Figure 5. Association between HSI values calculated from the AMM (based on AIC variable selection) and $(\mathbf{a}, \mathbf{c})$ total catch and fishing effort $( \pm \mathrm{SD})$ and $(\mathbf{b}, \mathbf{d})$ summed standardized monthly CPUE for albacore tuna in the SAO.
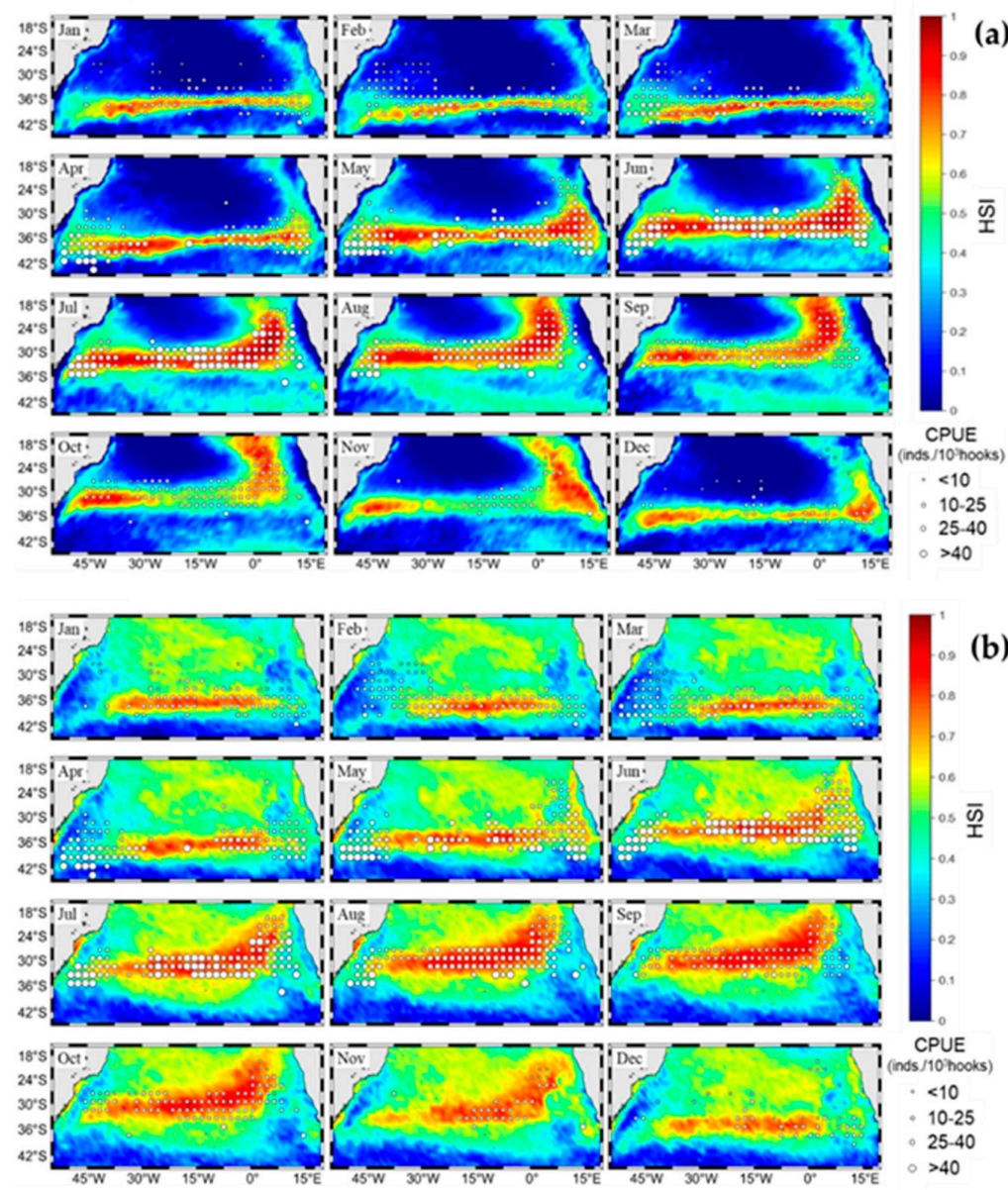

Figure 6. Monthly HSI predicted maps and albacore standardized CPUE using (a) an AMM model with SST and SSC data, and (b) an AMM model with SST, SSH, and EKE data. Open circles denote the scale of average CPUE standardization. 


\section{Discussion}

A total allowable catch was implemented in 2000 [37], and increasing efforts have been made to rebuild the albacore stock in the world's oceans, with a recent adoption of harvest control rules [56]. However, designing effective plans and employing practical tools to enhance the management of pelagic fish (e.g., albacore) should be conducted with an understanding of the ranges of key biological parameters, determinations of the spatial and temporal distribution of species, and investigations of the effects of environmental conditions; such plans and tools are valuable for stock rebuilding organizations (e.g., ICCAT) [36,57] and are even applicable to Taiwanese fleets, as the main fisheries of albacore tuna in the SAO. Remotely sensed environmental variables were employed to model the habitat suitability of albacore in the SAO during 2009-2015. An empirical AMM-derived habitat suitability model with two remotely sensed environmental variables, SST and SSC, was identified as an appropriate model for describing the habitat variance of albacore in the SAO. HSI $>0.6$ was identified in waters with optimal environmental ranges of SST and SSC (Table 2), highlighting areas of high probability of albacore presence (Figures 5 and 6). The albacore optimal habitat was detected in areas where SST and SSC were $16.5^{\circ} \mathrm{C}-19.5^{\circ} \mathrm{C}$ and $0.11-0.33 \mathrm{mg} / \mathrm{m}^{3}$, respectively. For oceans worldwide, preferential ranges for various biophysical environmental variables that affect albacore habitat and abundance have already been hypothesized $[6,9,17,36,45,58]$. The AMM-based HSI prediction maps for albacore characterized a substantial monthly suitable habitat variation that shifted northward from approximately $40^{\circ} \mathrm{S}$ in April to approximately $18^{\circ} \mathrm{S}$ in July to August. In addition, the high CPUE of albacore was recorded in areas with high HSI, representing a northeast direction. A low HSI increased in January in the north but decreased as winter (August) intensified. By contrast, the favorable habitat (HSI > 0.6) extended northward from $33^{\circ} \mathrm{S}$ in January to the waters of $18^{\circ} \mathrm{S}$ in August and then moved southward in December (Figure 6). Synchronously, the poor habitat created by decreasing temperature in southern waters, in combination with the $19^{\circ} \mathrm{CSST}$ isotherm extending to northern waters (Figure 7), may have led the albacore to concentrate even more northward-near $20^{\circ} \mathrm{S}-$ in August. Consequently, albacore schools, due to the west-to-east and northward development of the suitable habitat, migrated to the northeast of the SAO, thus increasing catch probability in July and August in that region.

SST is widely accepted as a key predictor of CPUE for albacore tuna $[39,59,60]$ due to its relation to albacore distribution limits. Moreover, migration is triggered by food availability, which is mainly indicated by SSC and optimal SST $[17,28,58,61]$. Recent findings have demonstrated that SST and SSC play significant roles in most abundance models of albacore distribution $[28,36,40,45]$. The length distribution of albacore tuna (Figure 8) highlighted the potential of feeding grounds of immature albacore near the temperate to subtropical area, which is as a function of the SST front [36]. It also specifies the spawning grounds around northwest subtropical to tropical waters, where lower food concentration in surface waters and high temperature are defined as suitable for spawning [62]. Furthermore, the distribution, migration, and catchability of tuna may be closely related to oceanic eddies and fronts $[8,9,28,63]$. However, albacore preferred different optimal ranges of MLD (45-105 m; Figure 4e), which may confirm daily or latitudinal vertical migration was derived through food availability [64-66] appearing in deeper mixed layer during the day and deeper waters at lower latitude [67]. 

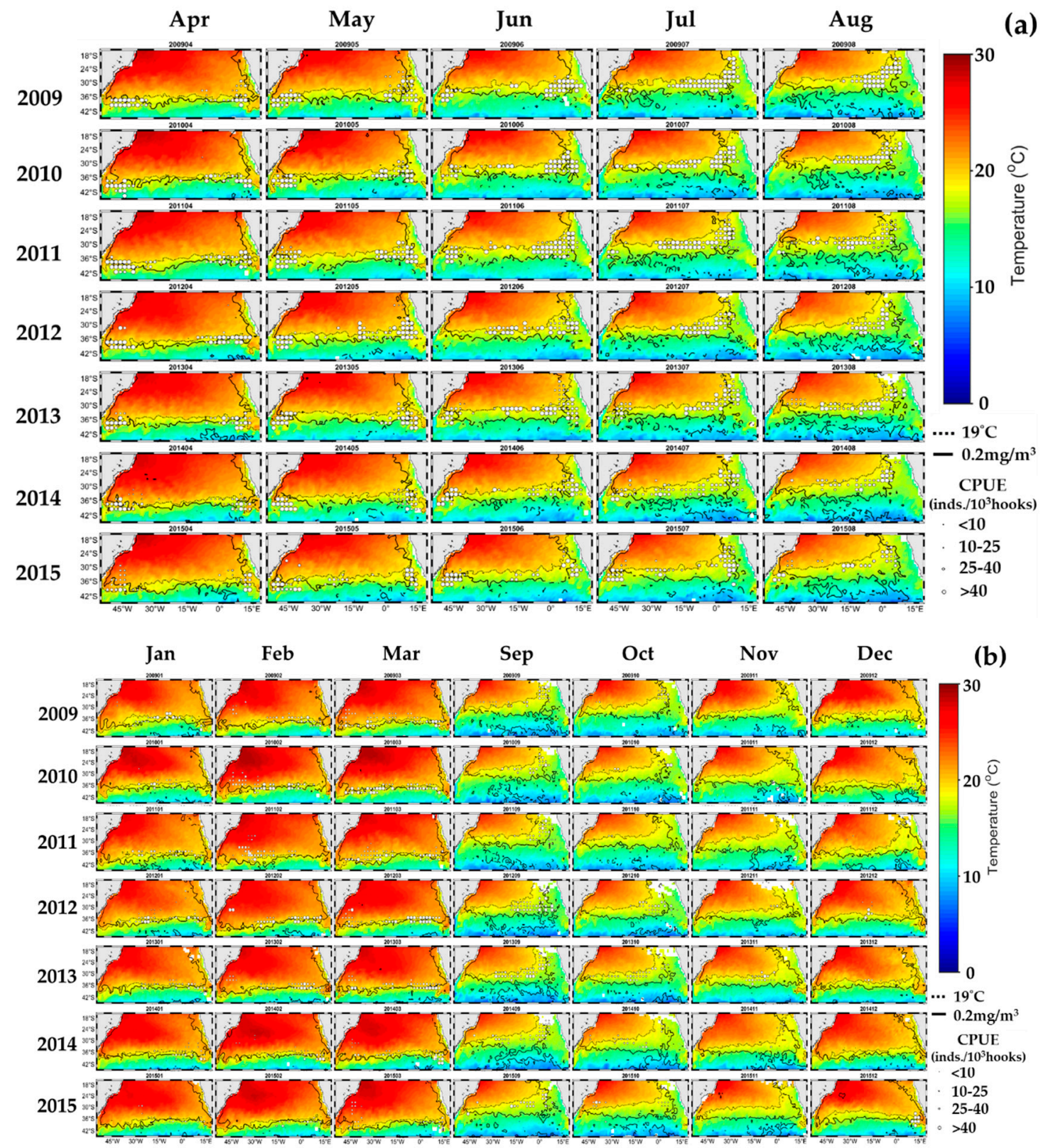

Figure 7. Annual geographical distribution of albacore CPUE associated with SST and SSC (a) during April to August (main fishing season) and (b) other months. The dotted line represents the $19{ }^{\circ} \mathrm{C}$ SST isotherm, and the black lines represent the $0.2 \mathrm{mg} / \mathrm{m}^{3}$ SSC isopleth in the current month and time delay of 1 month, respectively. 


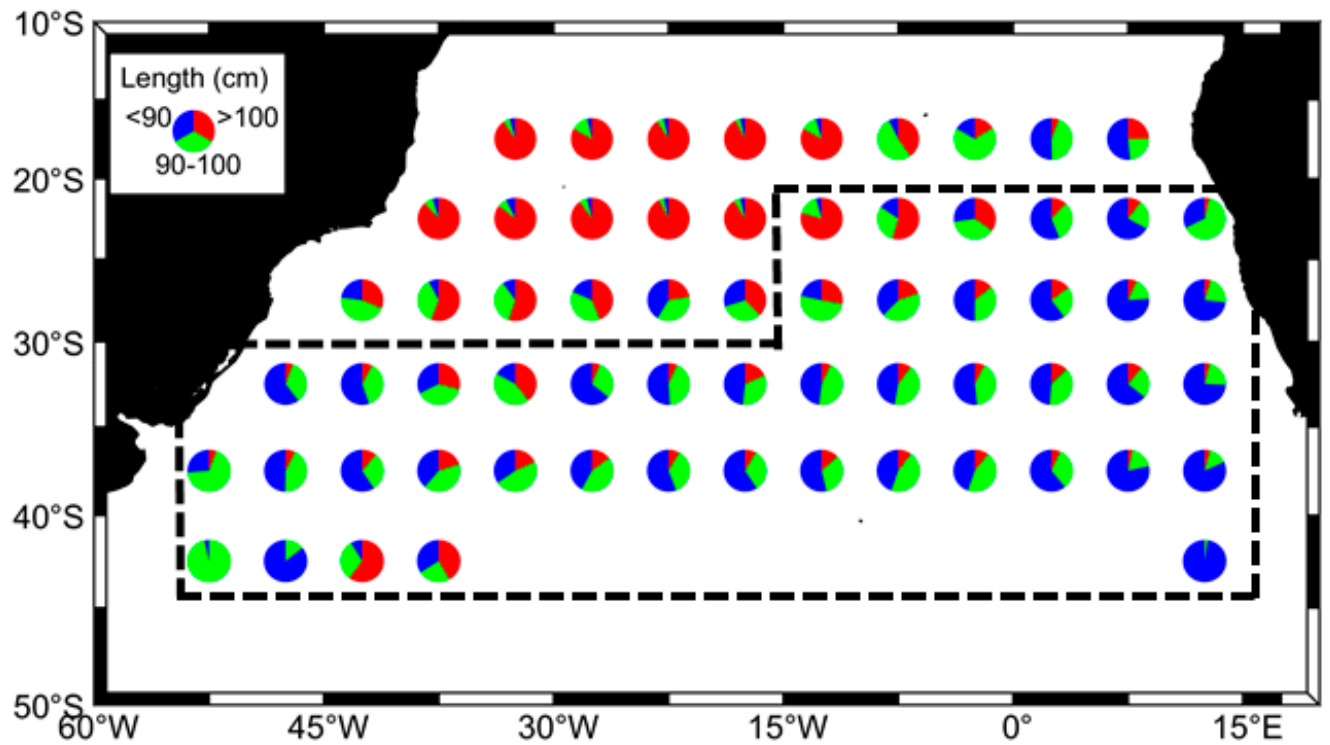

Figure 8. Length distribution of albacore tuna in feeding ground (dashed line) and spawning ground (outside line). At the spawning ground, the albacore tended to be longer than $100 \mathrm{~cm}$, whereas in the feeding ground, lengths were shorter [36].

The present study uncovered a significant increase in albacore CPUE in the SAO near the south side of the $19^{\circ} \mathrm{C} \mathrm{SST}$ isotherm and $0.2 \mathrm{mg} / \mathrm{m}^{3} \mathrm{SSC}$ isopleth front in the southern hemisphere (Figure 7). Abundance might be augmented by this combination of SST and SSC, commencing at the frontal section of surface convergence where cool, vertically well mixed, and highly productive surface waters on the south side of the $19{ }^{\circ} \mathrm{C}$ isotherm sink beneath the warm, stratified, and low productive waters on the north side $[28,63]$, eventually resulting in highly productive and suitable feeding areas for immature albacore schools in the SAO. This might be the cause of albacore schools aggregating in the south near the $19{ }^{\circ} \mathrm{C}$ isotherm. Previous reports have also discussed the importance of these conditions in relation to albacore abundance [9,28,38]. Polovina et al. [63] suggested that the contour level of $20^{\circ} \mathrm{C}$ isotherm and $0.2 \mathrm{mg} \mathrm{m}^{-3}$ isopleth, where water is cool, and vertical mixing of water caused higher chlorophyll in the surface, which resulted in the aggregation of higher albacore CPUE. Allain and Aloncle [68] investigated deeper water albacore habitats using bathythermograph casts. Upwelling is characterized by the vertical disposition of isotherms that bring cooler water to the surface. A thermocline between 25 and $30 \mathrm{~m}$ vertical depth having temperatures of 14 and $17^{\circ} \mathrm{C}$ in the deepest and shallowest area, respectively, might be a reason that tuna are located in a certain range of depth without their surface detection, as it inhabits a wide vertical range [36]. Moreover, albacore tuna swim diagonally or vertically to gain advantage over prey by warming their bodies, which might also be a good possible reason for albacore preferring habitats at different depths [45]. Nieto et al. [11] described that albacore tuna preferred warm water to reduce heat loss and maintain body temperature; this is also related to thermocline depth and upwelling. Hence, preferred biophysical environmental factors explain the location of areas of high probability associated with the position of frontal zones and suitable environment, where albacore prey is rich and the area appropriate for living. Overall, SST and SSC derived from multisatellite remote sensing can make a meaningful contribution to predicting distribution patterns and variation in tuna and tuna-like species abundance in the SAO.

In this study, we presented another AMM constructed using three variables (SST, SSH, and EKE) as an HSI model (Table 2). It provided equal AIC values; however, it presented lower adjusted $R^{2}$ $(r=0.63)$ compared with the best HSI model. Many studies in different albacore fishing regions have explored the importance of MLD, EKE, and SSH in relation to albacore abundance. For example, many have highlighted that the albacore's vertical patrolling behavior varies above or below MLD for food source $[28,36,65,67,69]$. Williams et al. [67] also concluded that albacore in temperate latitudes 
are limited to above MLD due to the availability of food in shallow waters. Our study of temperate latitudes confirmed that albacore appear in shallow water (MLD $<100 \mathrm{~m})$ and positive values of SSH. MLD is also correlated with SSH variation: the extension of SST cooling could cause convection, which enlarges MLD and reduces SSH (e.g., [70]). Furthermore, a subtropical SST front may have interannual variation associated with shifts in the wind [69] and has been assumed to be consistent with MLD and SSH variation (e.g., [71,72]). The role of EKE in apex predator aggregation $[16,19,73,74]$ has been explained by the action of nutrient injection into the euphotic zone $[75,76]$, resulting in phytoplankton blooms and eventually inducing secondary production [77]. Because the characteristics of frontal intensity and shifts in the position of regions of thermal gradients are less obvious [78], further investigations of possible mechanisms of fronts forming and tuna aggregation around the fronts are necessary $[4,79]$.

Assuming that environmental factors are the only variables influencing the habitat of South Atlantic albacore would be quite optimistic, however. In reality, despite the dynamicity of marine fisheries, climatic change, global warming, and various biotic and abiotic factors could alter tuna migration, food availability, catch rate, and stock indices, all of which are related to habitat $[45,56,58,60,80]$. Determining the precise mechanism(s) underlying suitable habitat is challenging; additionally, whether the interannual distribution shifts of species are mainly associated with other ocean-climate factors, prey abundance, or even another factor like fleet behavior [81] remains unclear. Hence, indirect habitat modeling using diet composition indicators (e.g., small pelagic fish, crustacean, and squid) and historical changes in hotspot habitat resulting from empirical habitat suitability models, such as that of the present study, and advanced modeling of population dynamics [82] could also be suggested as further research areas for the implementation of regional EBFM in the SAO.

\section{Conclusions}

In summary, multisatellite remotely sensed data were employed to construct an empirical HSI model for albacore in the SAO. An AMM-derived HSI model developed using the SI values of remotely sensed data was demonstrated to be the optimum empirical model for albacore HSI. The selected AMM model used two variables-SST and SSC - to detect the albacore-preferred habitat. The optimal habitat was detected in areas where SST and SSC were $16.5^{\circ} \mathrm{C}-19.5^{\circ} \mathrm{C}$ and $0.11-0.33 \mathrm{mg} / \mathrm{m}^{3}$, respectively. The HSI prediction maps for albacore suggested substantial monthly variation and a northward shift from $40^{\circ} \mathrm{S}$ in January to approximately $18^{\circ} \mathrm{S}$ in July to August. By contrast, an unfavorable habitat (HSI $<0.4$ ) was triggered by decreasing temperatures in waters north of $32^{\circ} \mathrm{S}$, and it also moved slightly southward in August, lying south of $40^{\circ} \mathrm{S}$, compared with the position north of $30^{\circ} \mathrm{S}$ in January to April.

Overall, because of the west-to-east northward extension of the suitable habitat, albacore schools move to the northeast of the SAO in June to August, thus increasing catch probability in that region. In addition, the suitable habitat detected using multisatellite remote sensing data was associated with areas of high CPUE, suggesting that high tuna abundance near eddy fields is associated with favorable SST and SSC. However, uncertain factors such as climatic change, global warming, and various biotic and abiotic factors (e.g., prey abundance or fleet behavior) that could influence the preferred albacore habitat were not considered in this study. To ensure the long-term sustainability of the tuna stocks under RFMO jurisdictions such as that of the ICCAT and enable successful regional EBFM in the SAO, future studies should elucidate mechanisms such as prey abundance, fleet behavior, and climatic effect interactions.

Supplementary Materials: The following are available online at http://www.mdpi.com/2072-4292/12/16/2515/s1, Table S1. Statistical result of CPUE and standardized CPUE (STD_CPUE), by monthly mean, Table S2. Statistical result of CPUE and standardized CPUE, for entire time series. 
Author Contributions: Conceptualization, A.H.V. and M.-A.L.; data curation, A.H.V. and M.-A.L.; formal analysis, M.-A.L. and C.-T.L.; methodology, M.-A.L.; resources, M.-A.L., J.-S.W., and Y.-C.W.; visualization, C.-T.L. and Y.-C.W.; writing-original draft, A.H.V.; writing—review and editing, M.-A.L., S.M., and Y.-C.W. All authors have read and agreed to the published version of the manuscript.

Funding: This research was financed by the Taiwan Council of Agriculture (106AS-10.1.5-FA-F1(4); 107AS-9.1.5-FA-F1(4)) and the Ministry of Science and Technology of Taiwan (MOST105-2611-M-019-011).

Acknowledgments: We truly appreciate the Overseas Fisheries Development Council of Taiwan for supplying the fishery data. The authors also acknowledge the ERDDAP data server of the National Oceanic and Atmospheric Administration (https://coastwatch.pfeg.noaa.gov/erddap/index.html) and HYCOM (Naval Research Laboratory at Stennis Space Center; http://www.hycom.org/) for multisatellite data. We thank Jun-Hong Wu for his assistance with IDL programming and multisatellite data analysis. The first author also appreciates Artemia \& Aquaculture Research Institute, Urmia University.

Conflicts of Interest: The authors declare no conflict of interest.

\section{References}

1. Belkin, I.M.; O'Reilly, J.E. An algorithm for oceanic front detection in chlorophyll and SST satellite imagery. J. Mar. Syst. 2009, 78, 319-326. [CrossRef]

2. Shimada, T.; Sakaida, F.; Kawamura, H.; Okumura, T. Application of an edge detection method to satellite images for distinguishing sea surface temperature fronts near the Japanese coast. Remote Sens. Environ. 2005, 98, 21-34. [CrossRef]

3. Wall, C.C.; Muller-Karger, F.E.; Roffer, M.A.; Hu, C.; Yao, W.; Luther, M.E. Satellite remote sensing of surface oceanic fronts in coastal waters off west-central Florida. Remote Sens. Environ. 2008, 112, 2963-2976. [CrossRef]

4. Lan, K.W.; Lu, H.J.; Shimada, T.; Kawamura, H.; Lee, M.A.; Hosoda, K.; Sakaida, F. Relationship between albacore (Thunnus alalunga) fishing grounds in the Indian Ocean and the thermal environment revealed by cloud-free microwave sea surface temperature. Fish. Res. 2011, 113, 1-7. [CrossRef]

5. Montgomery, D. Commercial applications of satellite oceanography. Earth Resour. Remote Sens. 1981, 24, $56-65$.

6. Laurs, R.M.; Fiedler, P.C.; Montgomery, D.R. Albacore tuna catch distributions relative to environmental features observed from satellites. Deep Sea Res. Part A Oceanogr. Res. Pap. 1984, 31, 1085-1099. [CrossRef]

7. Chen, X.; Tian, S.; Chen, Y.; Liu, B. A modeling approach to identify optimal habitat and suitable fishing grounds for neon flying squid (Ommostrephes bartramii) in the northwest pacific ocean. Fish. Bull. 2010, 108, $1-14$.

8. Zainuddin, M.; Saitoh, S.; Saitoh, K. Detection of potential fishing ground for albacore tuna using synoptic measurements of ocean color and thermal remote sensing in the northwestern North Pacific. Geophys. Res. Lett. 2004, 31. [CrossRef]

9. Zainuddin, M.; Saitoh, K.; Saitoh, S. Albacore (Thunnus alalunga) fishing ground in relation to oceanographic conditions in the western North Pacific Ocean using remotely sensed satellite data. Wiley Online Libr. 2008, 17, 61-73. [CrossRef]

10. Lan, K.W.; Lee, M.A.; Chou, C.P.; Vayghan, A.H. Association between the interannual variation in the oceanic environment and catch rates of bigeye tuna (Thunnus obesus) in the Atlantic Ocean. Fish. Oceanogr. 2018, 27, 395-407. [CrossRef]

11. Nieto, K.; Xu, Y.; Teo, S.L.H.; McClatchie, S.; Holmes, J. How important are coastal fronts to albacore tuna (Thunnus alalunga) habitat in the northeast pacific ocean? Prog. Oceanogr. 2017, 150, 62-71. [CrossRef]

12. Stuart, V.; Platt, T.; Sathyendranath, S. The future of fisheries science in management: A remote-sensing perspective. ICES J. Mar. Sci. 2011, 68, 644-650. [CrossRef]

13. Lan, K.W.; Nishida, T.; Lee, M.A.; Lu, H.J.; Huang, H.W.; Chang, S.K.; Lan, Y.C. Influence of the marine environment variability on the yellowfin tuna (Thunnus albacares) catch rate by the taiwanese longline fishery in the arabian sea, with special reference to the high catch in 2004. J. Mar. Sci. Tech. 2012, 20, 514-524. [CrossRef]

14. Klemas, V. Remote sensing of environmental indicators of potential fish aggregation: An overview. Baltica 2012, 25, 99-112. [CrossRef] 
15. Juan-Jordá, M.J.; Murua, H.; Arrizabalaga, H.; Dulvy, N.K.; Restrepo, V. Report card on ecosystem-based fisheries management in tuna regional fisheries management organizations. Fish Fish. 2018, 19, 321-339. [CrossRef]

16. Syamsuddin, M.; Saitoh, S.-I.; Hirawake, T.; Syamsudin, F.; Zainuddin, M. Interannual variation of bigeye tuna (Thunnus obesus) hotspots in the eastern Indian Ocean off Java. Int. J. Remote Sens. 2016, 37, 2087-2100. [CrossRef]

17. Arrizabalaga, H.; Dufour, F.; Kell, L.; Merino, G.; Ibaibarriaga, L.; Chust, G.; Irigoien, X.; Santiago, J.; Murua, H.; Fraile, I.; et al. Global habitat preferences of commercially valuable tuna. Deep Sea Res. Part II Top. Stud. Oceanogr. 2015, 113, 102-112. [CrossRef]

18. Lan, K.W.; Lee, M.A.; Lu, H.J.; Shieh, W.J.; Lin, W.K.; Kao, S.C. Ocean variations associated with fishing conditions for yellowfin tuna (Thunnus albacares) in the equatorial Atlantic Ocean. ICES J. Mar. Sci. 2011, 68, 1063-1071. [CrossRef]

19. Mugo, R.; Saitoh, S.I.; Nihira, A.; Kuroyama, T. Habitat characteristics of skipjack tuna (Katsuwonus pelamis) in the western North Pacific: A remote sensing perspective. Fish. Oceanogr. 2010, 19, 382-396. [CrossRef]

20. Su, N.J.; Yeh, S.Z.; Sun, C.L.; Punt, A.E.; Chen, Y.; Wang, S.P. Standardizing catch and effort data of the Taiwanese distant-water longline fishery in the western and central Pacific Ocean for bigeye tuna, Thunnus obesus. Fish. Res. 2008, 90, 235-246. [CrossRef]

21. Tian, S.; Chen, X.; Chen, Y.; Xu, L.; Dai, X. Standardizing CPUE of Ommastrephes bartramii for Chinese squid-jigging fishery in Northwest Pacific Ocean. Chin. J. Oceanol. Limnol. 2009, 27, 729. [CrossRef]

22. Maunder, M.N.; Hinton, M.G.; Bigelow, K.A.; Langley, A.D. Developing indices of abundance using habitat data in a statistical framework. Bull. Mar. Sci. 2006, 79, 545-559.

23. Maunder, M.N.; Thorson, J.T.; Xu, H.; Oliveros-Ramos, R.; Hoyle, S.D.; Tremblay-Boyer, L.; Lee, H.H.; Kai, M.; Chang, S.-K.; Kitakado, T. The need for spatio-temporal modeling to determine catch-per-unit effort based indices of abundance and associated composition data for inclusion in stock assessment models. Fish. Res. 2020, 229, 105594. [CrossRef]

24. Vayghan, A.H.; Zarkami, R.; Sadeghi, R.; Fazli, H. Modeling habitat preferences of Caspian kutum, Rutilus frisii kutum (Kamensky, 1901)(Actinopterygii, Cypriniformes) in the Caspian Sea. Hydrobiologia 2016, 766, 103-119. [CrossRef]

25. Vayghan, A.H.; Poorbagher, H.; Shahraiyni, H.T.; Fazli, H.; Saravi, H.N. Suitability indices and habitat suitability index model of Caspian kutum (Rutilus frisii kutum) in the southern Caspian Sea. Aquat. Ecol. 2013, 47, 441-451. [CrossRef]

26. Vayghan, A.H.; Fazli, H.; Ghorbani, R.; Lee, M.A.; SARAVI, H.N. Temporal habitat suitability modeling of Caspian shad (Alosa spp.) in the southern Caspian Sea. J. Limnol. 2016, 75, 210-223. [CrossRef]

27. Van der Lee, G.E.M.; Van der Molen, D.T.; Van den Boogaard, H.F.P.; Van der Klis, H. Uncertainty analysis of a spatial habitat suitability model and implications for ecological management of water bodies. Landsc. Ecol. 2006, 21, 1019-1032. [CrossRef]

28. Lee, M.A.; Weng, J.S.; Lan, K.W.; Vayghan, A.H.; Wang, Y.C.; Chan, J.W. Empirical habitat suitability model for immature albacore tuna in the North Pacific Ocean obtained using multisatellite remote sensing data. Int. J. Remote Sens. 2020, 41, 5819-5837. [CrossRef]

29. Wang, J.; Yu, W.; Chen, X.; Lei, L.; Chen, Y. Detection of potential fishing zones for neon flying squid based on remote-sensing data in the Northwest Pacific Ocean using an artificial neural network. Int. J. Remote Sens. 2015, 36, 3317-3330. [CrossRef]

30. Wang, W.; Zhou, C.; Shao, Q.; Mulla, D.J. Remote sensing of sea surface temperature and chlorophyll-a: Implications for squid fisheries in the north-west Pacific Ocean. Int. J. Remote Sens. 2010, 31, 4515-4530. [CrossRef]

31. Alabia, I.D.; Saitoh, S.I.; Igarashi, H.; Ishikawa, Y.; Imamura, Y. Spatial habitat shifts of oceanic cephalopod (ommastrephes bartramii) in oscillating climate. Remote Sens. 2020, 12, 521. [CrossRef]

32. Lan, K.W.; Chang, Y.J.; Wu, Y.L. Influence of oceanographic and climatic variability on the catch rate of yellowfin tuna (Thunnus albacares) cohorts in the Indian Ocean. Deep Sea Res. Part II Top. Stud. Oceanogr. 2019, 104681. [CrossRef]

33. Matsumoto, T. Standardization of CPUE for south Atlantic albacore (Thunnus alalunga) by the Japanese longline fishery using revised method. Collect. Vol. Sci. Pap. ICCAT 2017, 74, 584-597. 
34. Zhang, K.; Liu, Q.; Kalhoro, M.A. Application of a Delay-difference model for the stock assessment of southern Atlantic albacore (Thunnus alalunga). J. Ocean. Univ. China 2015, 14, 557-563. [CrossRef]

35. Lee, L.K.; Yeh, S.Y. Assessment of south Atlantic albacore resource based on 1959-2005 catch and effort statistics from ICCAT. ICCAT Collect. 2008, 62, 870-883.

36. Nikolic, N.; Morandeau, G.; Hoarau, L.; West, W.; Arrizabalaga, H.; Hoyle, S.; Nicol, S.J.; Bourjea, J.; Puech, A.; Farley, J.H.; et al. Review of albacore tuna, Thunnus alalunga, biology, fisheries and management. Rev. Fish Biol. Fish. 2017, 27, 775-810. [CrossRef]

37. ICCAT. Report of the 2013 Iccat North and South Atlantic Albacore Stock Assessment Meeting; Sukarrieta, Spain, 17-24 June 2013. Available online: https://www.iccat.int/Documents/Meetings/Docs/2013_ALB_ ASSESS_REP_ENG.pdf (accessed on 20 March 2020).

38. Zainuddin, M.; Kiyofuji, H.; Saitoh, K.; Saitoh, S.-I. Using multi-sensor satellite remote sensing and catch data to detect ocean hot spots for albacore (Thunnus alalunga) in the northwestern North Pacific. Deep Sea Res. Part II Top. Stud. Oceanogr. 2006, 53, 419-431. [CrossRef]

39. Chen, I.C.; Lee, P.F.; Tzeng, W.N. Distribution of albacore (Thunnus alalunga) in the Indian Ocean and its relation to environmental factors. Fish. Oceanogr. 2005, 14, 71-80. [CrossRef]

40. Lee, M.A.; Vayghan, A.H.; Liu, D.C.; Yang, W.C. Potential and prospective seasonal distribution of hotspot habitat of albacore tuna (Thunnus alalunga) in the South Indian Ocean using the satellite data. In Proceedings of the International Geoscience and Remote Sensing Symposium (IGARSS), Fort Worth, TX, USA, 23-28 July 2017.

41. Chang, F.C.; Yeh, S.Y. Standardized CPUE of South Atlantic albacore (Thunnus alalunga) based on Taiwanese longline catch and effort statistics dating from 1967 to 2012. Collect. Vol. Sci. Pap. ICCAT 2014, 70, 1234-1246.

42. Schaefer, K.M. Reproductive biology of tunas. In Fish Physiology; Academic Press: Cambridge, MA, USA, 2001; Volume 19, pp. 225-270. ISBN 1546-5098.

43. Marano, G.; De Zio, V.; Pastorelli, A.M.; Rositani, L.; Ungaro, N.; Vlora, A. Synopsis on the biology and fisheries on Thunnus alalunga (Bonnaterre, 1788). Biol. Mar. Medit. 1999, 6, 192-214.

44. Ortiz de Zárate, V.; Cort, J.L. Albacore (Thunnus alalunga, Bonnaterre) stock structure in the Atlantic Ocean, as inferred from distribution and migration patterns. In Proceedings of the ICCAT Tuna Symposium, Madrid, Spain, 10 June 1998; Beckett, J.E., Ed.; Volume 1, pp. 251-260.

45. Singh, A.A.; Sakuramoto, K.; Suzuki, N.; Roshni, S.; Nath, P.; Kalla, A. Environmental conditions are important influences on the recruitment of North Pacific albacore tuna, Thunnus alalunga. Appl. Ecol. Environ. Res. 2017, 15, 299-319. [CrossRef]

46. Pauly, D.; Zeller, D. Catch reconstructions reveal that global marine fisheries catches are higher than reported and declining. Nat. Commun. 2016, 7, 1-9. [CrossRef] [PubMed]

47. Wang, S.P. Data analysis and CPUE standardization of albacore caught by Taiwanese longline fishery in the Indian Ocean. IOTC-2019-WPTmT07 (DP)-14_Rev1. In Proceedings of the Working Party on Temperate Tuna (WPTmT), Kuala Lumpur, Malaysia, 14-17 January 2019.

48. Maunder, M.N.; Punt, A.E. Standardizing catch and effort data: A review of recent approaches. Fish. Res. 2004, 70, 141-159. [CrossRef]

49. Tian, S.; Chen, X.; Chen, Y.; Xu, L.; Dai, X. Evaluating habitat suitability indices derived from CPUE and fishing effort data for ommatrephes bratramii in the northwestern Pacific Ocean. Fish. Res. 2009, 95, 181-188. [CrossRef]

50. Chen, X.; Li, G.; Feng, B.; Tian, S. Habitat suitability index of chub mackerel (scomber japonicus) from july to september in the east china sea. J. Oceanogr. 2009, 65, 93-102. [CrossRef]

51. Lee, D.; Son, S.H.; Lee, C.I.; Kang, C.K.; Lee, S.H. Spatio-temporal variability of the habitat suitability index for the todarodes pacificus (japanese common squid) around south korea. Remote Sens. 2019, 11, 2720. [CrossRef]

52. Lee, D.; Son, S.; Kim, W.; Park, J.M.; Joo, H.; Lee, S.H. Spatio-temporal variability of the habitat suitability index for chub mackerel (scomber japonicus) in the east/japan sea and the south sea of south korea. Remote Sens. 2018, 10, 938. [CrossRef]

53. Hess, G.R.; Bay, J.M. A regional assessment of windbreak habitat suitability. Environ. Monit. Assess. 2000, 61, 239-256. [CrossRef]

54. Lauver, C.L.; Busby, W.H.; Whistler, J.L. Testing a GIS model of habitat suitability for a declining grassland bird. Environ. Manag. 2002, 30, 88-97. [CrossRef] 
55. Brooks, R.P. Improving habitat suitability index models. Wildl. Soc. Bull. 1997, 25, 163-167.

56. Merino, G.; Arrizabalaga, H.; Arregui, I.; Santiago, J.; Murua, H.; Urtizberea, A.; Andonegi, E.; De Bruyn, P.; Kell, L.T. Adaptation of north atlantic albacore fishery to climate change: Yet another potential benefit of harvest control rules. Front. Mar. Sci. 2019, 6. [CrossRef]

57. Hobday, A.J.; Hartmann, K. Near real-time spatial management based on habitat predictions for a longline bycatch species. Fish. Manag. Ecol. 2006, 13, 365-380. [CrossRef]

58. Dufour, F.; Arrizabalaga, H.; Irigoien, X.; Santiago, J. Climate impacts on albacore and bluefin tunas migrations phenology and spatial distribution. Prog. Oceanogr. 2010, 86, 283-290. [CrossRef]

59. Sagarminaga, Y.; Arrizabalaga, H. Spatio-temporal distribution of albacore (Thunnus alalunga) catches in the northeastern Atlantic: Relationship with the thermal environment. Fish. Oceanogr. 2010, 19, 121-134. [CrossRef]

60. Phillips, A.J.; Ciannelli, L.; Brodeur, R.D.; Pearcy, W.G.; Childers, J. Spatio-temporal associations of albacore CPUEs in the Northeastern Pacific with regional SST and climate environmental variables. ICES J. Mar. Sci. 2014, 71, 1717-1727. [CrossRef]

61. Lezama-Ochoa, A.; Boyra, G.; Goñi, N.; Arrizabalaga, H.; Bertrand, A. Investigating relationships between albacore tuna (Thunnus alalunga) CPUE and prey distribution in the Bay of Biscay. Prog. Oceanogr. 2010, 86, 105-114. [CrossRef]

62. Farley, J.H.; Williams, A.J.; Hoyle, S.D.; Davies, C.R.; Nicol, S.J. Reproductive dynamics and potential annual fecundity of South Pacific albacore tuna (Thunnus alalunga). PLoS ONE 2013, 8, e60577. [CrossRef]

63. Polovina, J.J.; Howell, E.; Kobayashi, D.R.; Seki, M.P. The transition zone chlorophyll front, a dynamic global feature defining migration and forage habitat for marine resources. Prog. Oceanogr. 2001, 49, 469-483. [CrossRef]

64. Briand, K.; Molony, B.; Lehodey, P. A study on the variability of albacore (Thunnus alalunga) longline catch rates in the southwest Pacific Ocean. Fish. Oceanogr. 2011, 20, 517-529. [CrossRef]

65. Cosgrove, R.; Arregui, I.; Arrizabalaga, H.; Goni, N.; Sheridan, M. New insights to behaviour of North Atlantic albacore tuna (Thunnus alalunga) observed with pop-up satellite archival tags. Fish. Res. 2014, 150, 89-99. [CrossRef]

66. Goni, N.; Arregui, I.; Lezama, A.; Arrizabalaga, H.; Moreno, G. Small scale vertical behaviour of juvenile albacore in relation to their biotic environment in the Bay of Biscay. In Tagging and Tracking of Marine Animals with Electronic Devices; Nielsen, J.L., Arrizabalaga, H., Fragoso, N., Hobday, A., Lutcavage, M., Sibert, J., Eds.; Springer: Cham, Switzerland, 2009; pp. 51-73.

67. Williams, A.J.; Allain, V.; Nicol, S.J.; Evans, K.J.; Hoyle, S.D.; Dupoux, C.; Vourey, E.; Dubosc, J. Vertical behavior and diet of albacore tuna (Thunnus alalunga) vary with latitude in the South Pacific Ocean. Deep Sea Res. Part II Top. Stud. Oceanogr. 2015, 113, 154-169. [CrossRef]

68. Allain, C.; Aloncle, H.; Wise, J.P. Albacore Migrations between Portugal and the Southwest of Ireland as a Function of Environmental Temperature Variation. Bulletin d'Information et Documentation de l'Institut Scientifique et Technique des Pêches Maritimes. 1969. Available online: http://www.documentation.ird.fr/ hor/fdi:010026596 (accessed on 14 February 2020).

69. Childers, J.; Snyder, S.; Kohin, S. Migration and behavior of juvenile North Pacific albacore (Thunnus alalunga). Fish. Oceanogr. 2011, 20, 157-173. [CrossRef]

70. De Boyer Montégut, C.; Madec, G.; Fischer, A.S.; Lazar, A.; Iudicone, D. Mixed layer depth over the global ocean: An examination of profile data and a profile-based climatology. J. Geophys. Res. Ocean. 2004, 109. [CrossRef]

71. Kobashi, F.; Kubokawa, A. Review on north pacific subtropical countercurrents and subtropical fronts: Role of mode waters in ocean circulation and climate. J. Oceanogr. 2012, 68, 21-43. [CrossRef]

72. Qiu, C.; Kawamura, H.; Mao, H.; Wu, J. Sea surface height and mixed layer depth responses to sea surface temperature in northwestern Pacific subtropical front zone from spring to summer. Ocean. Sci. Discuss. 2015, 12, 83-101. [CrossRef]

73. Teo, S.L.H.; Block, B.A. Comparative influence of ocean conditions on yellowfin and Atlantic bluefin tuna catch from longlines in the Gulf of Mexico. PLoS ONE 2010, 5, e10756. [CrossRef] [PubMed]

74. Teo, S.L.H.; Boustany, A.M.; Block, B.A. Oceanographic preferences of Atlantic bluefin tuna, Thunnus thynnus, on their Gulf of Mexico breeding grounds. Mar. Biol. 2007, 152, 1105-1119. [CrossRef] 
75. Olson, D.B.; Hitchcock, G.L.; Mariano, A.J.; Ashjian, C.J.; Peng, G.; Nero, R.W.; Podestá, G.P. Life on the edge: Marine life and fronts. Oceanography 1994, 7, 52-60. [CrossRef]

76. Olson, D.B. Rings in the ocean. Annu. Rev. Earth Planet. Sci. 1991, 19, 283-311. [CrossRef]

77. Bakun, A. Fronts and eddies as key structures in the habitat of marine fish larvae: Opportunity, adaptive response and competitive advantage. Sci. Mar. 2006, 70, 105-122. [CrossRef]

78. Burls, N.J.; Reason, C.J.C. Sea surface temperature fronts in the midlatitude South Atlantic revealed by using microwave satellite data. J. Geophys. Res. Ocean. 2006, 111. [CrossRef]

79. Sagarminaga, Y.; Arrizabalaga, H. Relationship of Northeast Atlantic albacore juveniles with surface thermal and chlorophyll-a fronts. Deep-Sea Res. Part II 2014, 107, 54-63. [CrossRef]

80. Lehodey, P.; Senina, I.; Dragon, A.C.; Arrizabalaga, H. Spatially explicit estimates of stock size, structure and biomass of North Atlantic albacore tuna (Thunnus alalunga). Earth Syst. Sci. Data 2014, 6, 317-329. [CrossRef]

81. Chust, G.; Goikoetxea, N.; Ibaibarriaga, L.; Sagarminaga, Y.; Arregui, I.; Fontán, A.; Irigoien, X.; Arrizabalaga, H. Earlier migration and distribution changes of albacore in the Northeast Atlantic. Fish. Oceanogr. 2019, 28, 505-516. [CrossRef]

82. Senina, I.N.; Lehodey, P.; Hampton, J.; Sibert, J. Quantitative modelling of the spatial dynamics of South Pacific and Atlantic albacore tuna populations. Deep Res. Part II Top. Stud. Oceanogr. 2019, 104667. [CrossRef]

(C) 2020 by the authors. Licensee MDPI, Basel, Switzerland. This article is an open access article distributed under the terms and conditions of the Creative Commons Attribution (CC BY) license (http://creativecommons.org/licenses/by/4.0/). 